\title{
Dietary Oils and Phospholipids Containing n-3 Highly Unsaturated Fatty Acids Suppress 2,4-Dinitro-1- fluorobenzene-induced Contact Dermatitis in Mice
}

\author{
Kazuya MoRIzawa*1, Yoko I.Tomobe*2, Mamoru TsuchidA*2, Yoshio NaKano*2 \\ Hidehiko HIBINo*2 and Yukihisa TANAKA*2 \\ *1 NOF Corporation Food Research Laboratory \\ (4-18-11, Toshima, Kita-ku, Tokyo 114-0003) \\ *2 NOF Corporation Tsukuba Research Laboratory \\ (5-10, Tokodai, Tsukuba-shi, Ibaraki-ken 300-2635)
}

\begin{abstract}
Dietary perilla oil, tuna oil and salmon roe phospholipids (fish roe PL) containing n-3 polyunsaturated fatty acids were compared with n-6 fatty acid-rich corn oil for their anti-inflammatory activities in the contact hypersensitivity reaction in the ears of mice sensitized with 2,4-dinitro-1fluorobenzene (DNFB). Suppression of ear swelling was most active with fish roe PL followed by tuna oil and Saibokuto, a traditional Chinese medicine, when compared with the corn oil diet group ; perilla oil enriched with $\alpha$-linolenic acid (n-3) tended to suppress the ear swelling, but the effect was not statistically significant. Infiltration of inflammatory CD4-positive T lymphocytes into the ears was suppressed by fish roe PL. Fish roe PL diet suppressed the expression of mRNAs for IFN- $\gamma$, IL- 6 and IL- $1 \beta$ in the ears. These results suggest that tuna oil and fish roe PL may be effective in suppressing delayed-type hypersensitivity.
\end{abstract}

Key words : n-3 Highly unsaturated fatty acid, Contact hypersensitivity reaction, Contact dermatitis, Anti-inflammation, Expression of cytokine mRNA

\section{Introduction}

Many researchers have reported that an intake of polyunsaturated fatty acid (PUFA), especially $\mathrm{n}-3$ PUFA has a beneficial role in the prevention of cardiovascular diseases $^{1,2)}$, which is, at least in part, due to reduced atherosclerosis ${ }^{3)}$. Eicosapentaenoic acid (EPA; 20:5), in particular, has been shown to be a useful agent in the prevention of hypertriglyceridemia ${ }^{4)}$ and osteoporosis ${ }^{5)}$. In the last decade, there has been considerable interest in the effects of different types of dietary PUFA on the immune system ${ }^{6}$. This interest in the immunomodulatory effects of fatty acids arises from epidemiological studies which showed that populations, such as the Inuit who consume large quantities of fish oil rich in n-3 PUFA EPA and docosahexaenoic acid (DHA ; $22: 6$ ), have a very

Corresponding author: Yukihisa TANAKA low incidence of inflammatory and autoimmuune problems $^{6}$. Further, many clinical studies indicate that fish oil supplementation of the human diet has beneficial effects in acute and chronic inflammatory conditions ${ }^{7) ~ 13)}$. Laboratory animals fed on diets rich in n-3 PUFA (Canola, linseed, fish oil), particularly those containing fish oil, have increased immunosuppression ${ }^{14 \sim 17)}$. $\mathrm{Arm}^{18)}$ has reported that fish oil supplementation ameliorated the symptoms of asthmatic subjects. Bjørneboe ${ }^{19)}$ demonstrated an improvement in the condition of atopic dermatitis patients after treatment with dietary Max-Epa (18\% EPA and 12\% DHA). The mechanism underlying skin lesion formation, in atopic dermatitis, has remained unclear except that there is a delayed hypersensitivity reaction against environmental substances ${ }^{20,21)}$ or an $\mathrm{Ig}-\mathrm{E}$ mediated hypersensitivity reaction against food or inhaled allergens $\mathrm{s}^{22,23)}$. The eczematous. skin lesions contain cytokine-producing, CD-4 positive T cells 
(T-helper cells, Th cells ${ }^{24), 25)}$ which have been divided into two subclasses depending on their cytokine secretion pattern : the Th1-like subtype, which is characterized by predominant production of interferon (IFN)- $\gamma$, and interleukin (IL)-2 and the Th2-like subtype, by its synthesis of IL- ${ }^{26)}$. In previous studies $85 \%$ of skin samples obtained from chronic eczematous lesions of atopic dermatitis patients, were found to contain increased levels of IFN- $\gamma$ mRNA, whereas increased IL-4 mRNA expression was observed only in $25 \%$ to $30 \%$ of cases $^{23)}$. In those atopic dermatitis patients whose skin disease responded to treatment, the increased IFN- $\gamma$ mRNA, but not the increased IL-4 mRNA levels, were down-regulated. These studies indicate that the Th1-like cytokine IFN- $\gamma$ plays a major role in the maintenance of chronic eczematous lesions in atopic dermatitis patients. It has already been reported that IFN- $\gamma$, among the several Th1types of cytokine, is especially important for the formation of a contact hypersensitivity reaction $(\mathrm{CHR})^{27}$. Although there are limitations to the use of the CHR in mice as a model for chronic atopic dermatitis, it is one approach for studying the late phase of this disease.

In our study we investigated the immunomodulatory effects of dietary edible oils containing n-3 PUFA, fed at the level of $4.8 \mathrm{wt} \%$ of the total diets, on the inflammatory response, in the ears of mice sensitized with 2,4-dinitro-1-fluorobenzene (DNFB), in the challenge phase of CHR. Corn oil, $4.8 \mathrm{wt} \%$, was used as the control diet. We show that perilla oil, fish oil and the phospholipid from salmon roe (fish roe PL) suppressed the ear swelling and the expression of Th1-type cytokines and decreased the infiltration of inflammatory cells into the challenge phase of CHR.

\section{Experimental}

\section{$2 \cdot 1$ Diets}

The low fat diet was obtained from Clea Japan Inc. (Yokohama Japan). To supply the essential fatty acid, linoleic acid, all diets contained $1.2 \mathrm{wt} \%$ safflower oil. The test diets and control diet contained $4.8 \mathrm{wt} \%$ of test oils and corn oil, respectively. Perilla oil and tuna oil, which contains more DHA than fish oil made from anchovies, were products of NOF Corp. (Tokyo Japan). Fish roe PL was extracted from salmon roe by the method of Folch ${ }^{28}$ and then fractionated by
Table 1 The Fatty Acid Composition of Test Diets (GC\%).

\begin{tabular}{l|r|r|r|r}
\hline & Corn oil & Tuna oil & Fish roe PL & Perilla oil \\
\hline $16: 0$ & 11.2 & 10.6 & 13.1 & 7.1 \\
$16: 1$ & 0.2 & 4.9 & 1.4 & 0.5 \\
$18: 0$ & 2.2 & 2.2 & 8.7 & 1.9 \\
$18: 1$ & 23.9 & 14.5 & 11.9 & 8.0 \\
$18: 2$ & 61.4 & 16.2 & 15.5 & 26.1 \\
$18: 3(\mathrm{n}-3)$ & - & 0.6 & 0.2 & 50.5 \\
$20: 4(\mathrm{AA})$ & - & 1.8 & 2.0 & - \\
$20: 5(\mathrm{EPA})$ & - & 8.9 & 9.0 & - \\
$22: 6(\mathrm{DHA})$ & - & 21.2 & 25.1 & - \\
others & 1.1 & 19.1 & 13.1 & 5.9 \\
\hline
\end{tabular}

Each diet contained $1.2 \mathrm{wt} \%$ of safflower oil and $4.8 \mathrm{wt} \%$ of test oil

cold acetone. The extract contained mainly triacylglycerol, phosphatidylcholine and phosphatidylethanolamine (in a ratio of $1: 8: 1$ by weight). Saibokuto (Tsumura Inc. Japan) which is an antiinflammatory Chinese medicine was added to the control diet $(1.0 \mathrm{wt} \%)$ as a positive control (Saibokuto diet). The fatty acid compositions of the test lipids are shown in Table 1. All diets were divided into small packages and stored at $4{ }^{\circ} \mathrm{C}$ and, to minimize lipid peroxidation, were provided fresh to the mice every day.

\subsection{Feeding Design and Induction of CHR}

Female, 4 week old, ddy mice obtained from Charles River Japan Inc. (Tokyo Japan) were held for one week and then divided into four groups ( $\mathrm{n}$ =4). Body weight was measured twice a week. After 23 days of feeding the test diets, the back hair of the mice was shaved. On the next day, the shaved backs of the mice were treated with $0.1 \mathrm{ml}$ of $0.5 \%$ DNFB diluted with an acetone/olive oil mixture $(4: 1 \mathrm{v} / \mathrm{v})$ to induce the inflammatory reaction (Induction step). After 5 days, $20 \mu$ l of the same DNFB mixture was applied to the sensitized mouse ears (Challenge step). At $6 \mathrm{~h}$ and $24 \mathrm{~h}$ after the challenge, the thicknesses of the mouse ears was measured using a thickness-gauge (OZAKI MFG. Co. LTD., Tokyo) and an increase in thickness was defined as ear swelling.

\subsection{Histopathological Analysis}

Twenty four hours after the challenge, the mice were sacrificed and their ears embedded in TissueTek OTC (Miles; Elkhart, IN) and frozen using dry ice/acetone. Serial $6 \mu$ sections were cut on a cryostat and placed on poly-L-lysine-coated slides 
Table 2 Histopathological Findings of Test Animals (mean $\pm \mathrm{SD}$ ).

\begin{tabular}{l|c|c}
\hline & Inflammatory cell infiltration & Edema \\
\hline Corn oil & $4.0 \pm 0.0$ & $4.0 \pm 0.0$ \\
Saibokuto & $3.0 \pm 0.0$ & $3.8+0.5$ \\
Fish roe PL & ${ }^{*} 2.5 \pm 0.6$ & ${ }^{*} 2.8 \pm 0.5$ \\
\hline
\end{tabular}

1:very slight, 2 :slight, 3:medium, 4:severe, 5:more severe

${ }^{*}: \mathrm{p}<0.01$ Significantly different from corn oil diet group $(n=4)$.

(two sections per slide). The slides of frozen sections were stained with hematoxylin-eosin solution.

Infiltration of inflammatory cells into the epidermis and the severity of edema were observed and ranked by degree in one of five levels : rank 1, very slight; rank 2, slight; rank 3, medium; rank 4, severe and rank 5, most severe (Table 2).

\section{$2 \cdot 4$ Immunohistochemistry}

Serial $8 \mu \mathrm{m}$ sections were cut on a cryostat and placed on poly-L-lysine-coated slides (two sections per slide). Slides containing frozen sections were defrosted and dried at room temperature (RT) for $1 \mathrm{~h}$, fixed in cold acetone for $10 \mathrm{~min}$ and allowed to dry at RT for $10 \mathrm{~min}$. After washing in phosphate buffered saline (PBS) $(5 \min \times 3)$, non-specific binding sites were blocked with block ace (Dainippon Seiyaku Inc. Japan). Excess solution was removed, the sections circled with a waterproof pen (Dako ; Glosstrup, Denmark), and then incubated with the primary monoclonal antibody (MAB), anti-mouse CD4 (L3/T4) (Cedarlane Lab. Ltd., Canada) or anti-mouse CD $8 \alpha$ (KT15) (Serotec Ltd., Oxford England) at $37^{\circ} \mathrm{C}$ for $1 \mathrm{hr}$. All MABs against mouse antigens were rat immunoglobulin $\mathrm{G}(\mathrm{IgG})$ and the diluent was $10 \%$ block ace. Negative control slides were incubated in diluent alone. After washing in PBS the slides were incubated with biotinylated rabbit anti rat IgG pre-absorbed with powdered mouse liver, followed by avidin-biotinylated horseradish peroxidase complex $(\mathrm{ABC})$ and diaminobenzidine according to the Vectastain protocol (Vector, USA). For individual slides, the nuclei were counterstained with methyl green (Vector, USA).

\subsection{Expression of Cytokine mRNA}

Cytokine mRNA expression was measured by the reverse transcription-polymerase chain reac- tion (RT-PCR). The ears were taken from the mice $24 \mathrm{~h}$ after the challenge and homogenized with $1.0 \mathrm{ml}$ of $4 \mathrm{M}$-guanidium isothiocyanate buffer. After this, the total RNA was extracted and reverse transcribed to cDNA using Moloney Murine Leukemia Virus (M-MuLV) reverse transcriptase and a random primer [pd $\left.(\mathrm{N})_{6}\right]$ (Amersham Pharmacia Biotech, Sweden). Identical amounts of cDNA, based on the expression of glyceraldehyde-phosphate dehydrogenase (GAP$\mathrm{DH})$ as the house-keeping gene, were subjected to 35 cycles of PCR with cytokine primers (Clontec Inc.). The products were electrophoresed on a $1.0 \%$ agarose gel and visualized by ethidium bromide staining. The samples were screened using the computer software Bioimage (Bioimage Japan Inc. Tokyo Japan, Version 0.81) and the relative amounts of cytokine cDNA of each sample was calculated.

\subsection{Data Analysis}

The data were expressed as the mean $\pm \mathrm{SD}$ of four mice fed each diet. The data were analyzed by ANOVA and Bonferroni's test. A p value of less than 0.05 was considered to be statistically significant.

\section{Results}

\section{$3 \cdot 1$ Mouse Growth}

The final body weights, and therefore the total growth, did not differ among the groups fed on the different diets (data not shown) and no side-effects were observed among mice fed on the diets described.

\section{$3 \cdot 2 \quad$ Ear Swelling}

The differences in ear thickness (mean $\pm \mathrm{SD}$ ) before and after the challenge (ear swelling) are shown in Fig. $1 \mathbf{A}$ and $\mathbf{1 ~ B}$. The ear swelling of mice fed the corn oil diet had increased in a time dependent manner in the early late phase $(6 \mathrm{~h}$ after the challenge). However, the ear swelling of the mice fed tuna oil and fish roe PL were significantly suppressed compared with that of the mice fed the corn oil diet $(\mathrm{p}<0.05$, and $\mathrm{p}<0.01$ respectively) during this period and this continued to be apparent in mice fed both diets in the late phase ( $24 \mathrm{~h}$ after the challenge) $(\mathrm{p}<0.01)$.

The mean value of the ear swelling of the mice fed perilla oil was also suppressed compared with that of the mice fed on the corn oil diet. This difference was not statistically significant but this is 
A

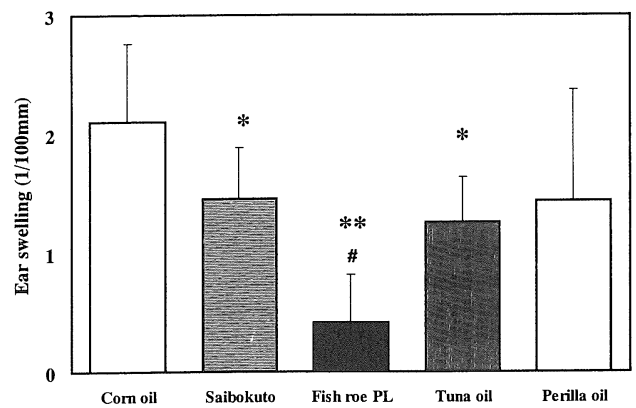

B

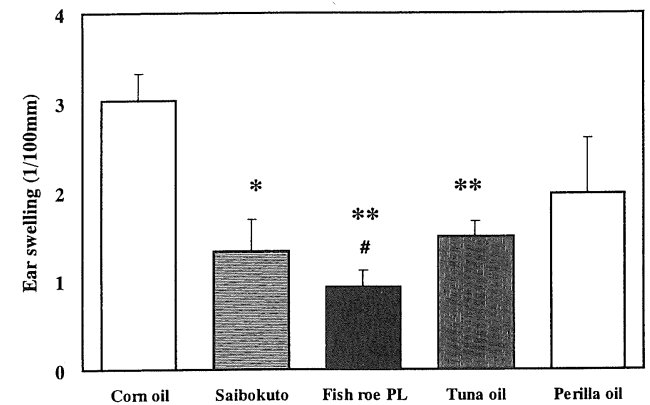

Fig. 1 Ear Swelling of Mice Fed Test Diets 6 Hours (A) and 24 hours $(\mathbf{B})$ after the Challenge. ${ }^{*} \mathrm{P}<0.05$ : significantly different from the corn oil diet group. ${ }^{* *} \mathrm{P}<0.01$ : significantly different from the corn oil diet group. \# $\mathrm{P}<0.01$ : significantly different from tuna oil diet group. (one-way ANOVA followed by Bonferroni's test).

The data are expressed as mean $\pm S D(n=4)$.

probably due to the large standard deviation (SD) in this group. The ear swelling of the mice fed the fish roe PL was the lowest of all groups and was significantly suppressed compared with that of those fed the tuna oil diet $(\mathrm{p}<0.01)$. This latter observation is curious as the fatty acid composition of fish roe PL is similar to that of tuna oil.

\section{$3 \cdot 3$ Histopathological Analysis}

Figure 2 shows the photomicrographs of the ears, stained with hematoxylin and eosin, of the mice fed corn oil and fish roe PL that exhibited the most suppression of their inflammation. On histological examination, $24 \mathrm{~h}$ after the challenge, spongiosis (paracytic edema of the epidermis and corium) and mononuclear cell infiltration into the epidermis were observed in the ear tissues from the mice fed the corn oil diet. Considerable infiltration of the lymphocytes (mostly monocytes) was also observed at the stratum reticular. Typical photographs are shown in Fig. 2 A. The number of infiltrated inflammatory cells in the ear tissues
A

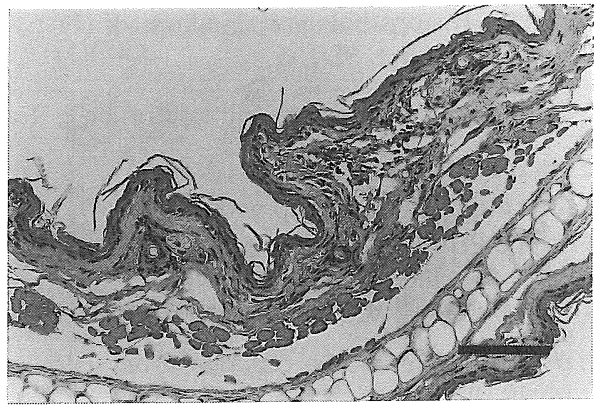

B

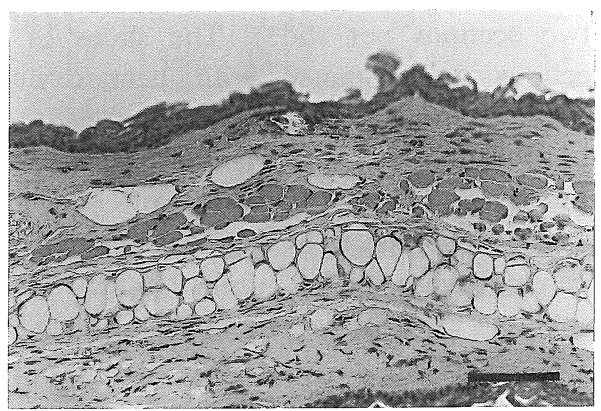

Fig. 2 Photomicrographs of the Mouse Ear Stained with Hematoxyline and Eosin. A : The ear of the mouse fed the control 24 hours after the challenge. $\mathbf{B}$ : The ear of the mouse fed fish roe PL 24 hours after challenge.

One bar equals $200 \mu \mathrm{m}$.

from mice fed the fish roe PL diet was reduced compared with those from mice fed the corn oil diet (Fig. 2 B). The severity of the ear tissue damage sustained by the mice fed each diet is shown in Table 2. Formation of focal granulation tissue in the dermis was not observed in the ear tissues from the mice on the fish roe PL diet $24 \mathrm{~h}$ after the challenge.

\section{$3 \cdot 4$ Immunohistological Study}

Results obtained $24 \mathrm{~h}$ after the challenge are shown in Fig 2. Infiltration of CD4-positive cells into the corium was observed in the ear tissues from mice fed the corn oil diet, (Fig. 3 A) whereas this was considerably less in tissues from the mice fed fish roe PL (Fig. $3 \mathbf{B}$ ). In the ear tissues from the mice fed the corn oil diet, some infiltration of CD8-positive cells into the corium, which was less than that of CD4-positive cells, was also observed.

$3 \cdot 5$ The Expression of Cytokines in the Ear Tissues from Mice in the Challenge Phase of CHR

We examined the cytokine mRNA expressed at the CHR sites (Fig. 4). Twenty four hours after 
A

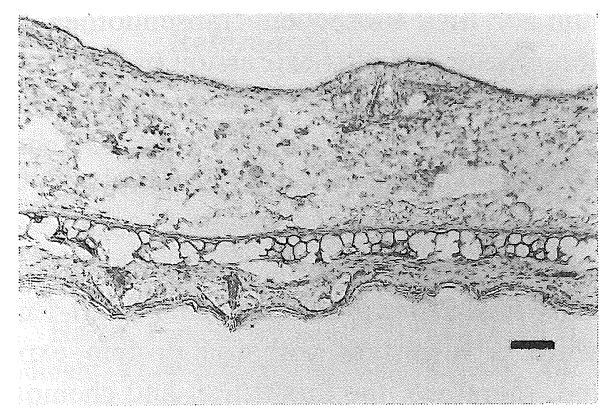

B

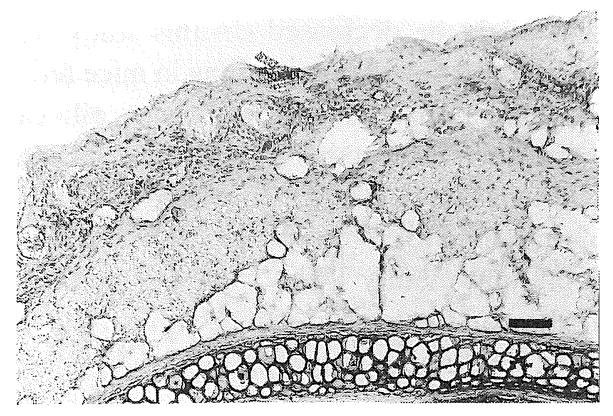

Fig. 3 Immunohistochemical Analysis. A : The ear of the mouse fed the control diet 24 hours after challenge. $\mathbf{B}$ : The ear of the mouse fed fish roe PL diet 24 hours after the challenge.

One bar equals $100 \mu \mathrm{m}$.

the challenge IL- $1 \beta$, IL-2, IL- 6 and IFN- $\gamma$, but not IL-4, IL-3 and TNF- $\alpha$ mRNA were expressed in the ear tissues from the mice fed the control diet. The expression of IL- $1 \beta$ and IFN- $\gamma$ mRNA was less in the ear tissues from the mice fed fish roe PL than that observed from mice fed the corn oil significantly. The expression of IL-6 mRNA was tend to be less in the ear tissues from the mice fed fish roe PL than that from mice fed the corn oil, but not significantly. Under these conditions, the level of GAPDH mRNA did not change.

\section{Discussion}

In this study we have examined the antiinflammatory and immunosuppressive effects of dietary oils and phospholipids that contained n-3 PUFA such as $\alpha$-linolenic acid (ALA), EPA and DHA, in a rodent contact dermatitis model. Generally it is thought that inflammatory mediators are generated from PUFA through an arachidonate cascade and play important roles in the development of the inflammatory process. Arachidonic acid (AA) is converted to 2 series of prostaglandins (PGs) and 4 series of leukotrienes (LTs) which are all mediators of inflammation. In particular the 4 series of LTs intensify neutrophil chemotactic responsiveness in the development of the inflammatory process. However, EPA displaces AA from macrophage phospholipids and effectively competes with it for cyclooxygenase and lipoxygenase binding sites to foster the formation of eicosanoids (e.g. thromboxane (TX) $\mathrm{A}_{3}, \mathrm{LTB}_{5}$ and $\mathrm{PGE}_{1}$ ) which have relatively lower inflammatory properties ${ }^{29)}$ than those generated
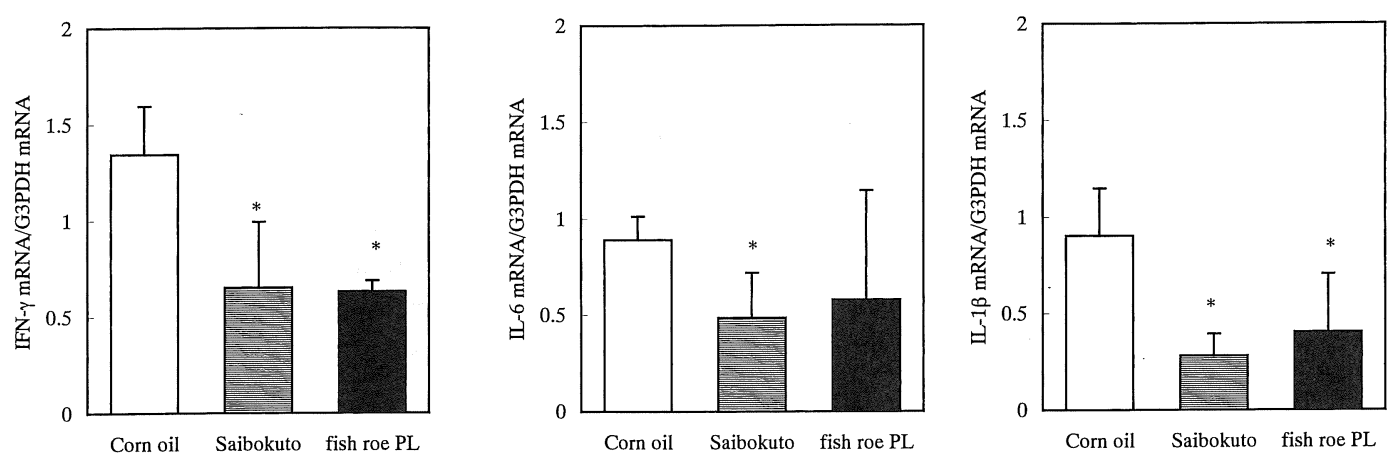

Fig. 4 Expression of Cytokine mRNAs in the Ears of Mice Fed Corn Oil, Saibokuto and Fish roe PL diet $24 \mathrm{~h}$ after the Challenge. Total RNA from each sample was used and subjected to RT-PCR analysis. For estimation of similar amounts of cDNA to be used for the PCR, samples were screened for the expression of GAPDH as a housekeeping gene and relative amounts of cDNA were calculated using computer software from Bioimage.

* $: \mathrm{P}<0.05$ : significantly different from the corn oil diet group.

The data are expressed as mean $\pm S D(n=4)$. 
from AA (e.g., TXA 2 and $\mathrm{LTB}_{4}$ ). Palombo ${ }^{30}$ reported that rats given an EPA enriched diet had lower amounts of $\mathrm{TXA}_{2} / \mathrm{A}_{3}$ and $\mathrm{LTB}_{4} / \mathrm{B}_{5}$ in the supernatants of the alveolar macrophages exposed to endotoxin in vitro than those in rats given a standard diet enriched with linoleic acid. The suppression of inflammatory responses by EPA might be due to some adverse effect on the arachidonate cascade such that the eicosanoid products are not formed.

Krokan $^{31}$ argued that, as substituting DHA for AA in the phospholipids of the cell membrane was more difficult than substituting EPA, the suppressive effect of DHA on the arachidonate cascade was likely to be less than that of EPA. In contrast, Corey $^{32)}$ showed that DHA did inhibit AA conversion to $\mathrm{PGE}_{2}$ in an in vitro experiment. Thus, these authors concluded that DHA did affect the arachidonate cascade. DHA also suppressed the production of platelet activated factor (PAF) which occurs following stimulation of cultured Eol1 cells by the calcium ionophore A23187 $7^{33)}$. Matsumoto $^{34)}$ reported 1-oleic 2-docosahexaenoic phosphatidylcholine inhibited 5-lipoxygenase (5LO) activity. These various studies indicate that DHA might well suppress the inflammatory response through modulation of the arachidonate cascade in a similar way to EPA and the effects of both EPA and DHA on the inflammatory response could be explained by the inhibition of this cascade.

To elucidate the immunosuppressive effects of n-3 PUFA, we used the mouse CHR model in which inflammation is induced with DNFB. It has been reported that ear swelling is at its worst approximately $24 \mathrm{~h}$ after administration of DNFB and is ameliorated $48 \mathrm{~h}$ after the challenge, so this reaction in the mouse is based on a chronic delayed type hypersensitivity (DHT or type IV hypersensitivity ${ }^{277}$. It was also reported that $24 \mathrm{~h}$ after the challenge IFN- $\gamma$, IL- 6 , IL- $1 \beta$ mRNA were expressed in the ear tissues of mice and $48 \mathrm{~h}$ after the challenge IL-2, IL- 4 and TNF- $\alpha$ mRNA were additionally expressed ${ }^{27}$. From results of analysis of IFN- $\gamma$ knockout mice and using anti INF- $\gamma$ antibody the authors suggested that the expression of IFN- $\gamma$ among several Th1-like cytokines is especially important for the formation of $\mathrm{CHR}^{27}$.

An inflammatory reaction is induced by the adhesion of circulating leukocytes on the endothe- lium and their subsequent transendothelial migration. The endothelial expression of the endothelial leukocyte adhesion molecules are important in this mechanism $^{35), 36)}$. DeCaterin ${ }^{37)}$ reported that DHA inhibited cytokine-stimulated expression of the endothelial leukocyte adhesion molecule, VCAM1. Their results suggested that dietary DHA might cause a decrease in the level of VCAM-1 mRNA, which is consistent with the protein expression and, therefore, the infiltration and chemotaxis of T-cell, monocytes and neutrophils into endothelial cells might be decreased. In this study we found that suppression of ear swelling in mice fed fish roe PL compared with those fed corn oil, caused a decrease in the number of infiltrated CD4-positive cells in lesion sites and a decrease in the expression of inflammatory cytokine mRNAs. The results imply that dietary DHA suppresses inflammation in the ear tissues sensitized with DNFB through these continuous reactions and suggest that not only EPA but also DHA, in its own right, plays an important role in inflammatory suppression.

Although the fatty acid composition of tuna oil was very similar to that of fish roe PL, the suppressive ability of fish roe PL was greater than that of tuna oil. The significant difference observed was probably due to the difference in the molecular compositions which in tuna oil was predominantly triacylglycerol and in fish roe was phospholipid. We hypothesize that this result is likely to arise from differences in the efficiency of the lipid absorption in the small bowel and lipid accumulation in cell membranes of skin. However, Masuzawa $^{38)}$ reported that DHA in phospholipids from squid was absorbed and accumulated in some organs at the same rate as DHA in triacylglycerol, but there was no information on the accumulation in the skin cell memebranes. To confirm our hypothesis we are currently analyzing rates of different lipid absorption and accumulation.

\section{Acknowledgment}

We thank Dr. Eiji Terada (Kitasato University, Sagamihara Japan) who passed away in the winter of 1997, for his many useful suggestions. We pray for the repose of his soul.

(Received Mar. 31, 1999 ; Accepted Oct. 19, 1999) 


\section{References}

1) S.D. Kristensen, R. DeCarterina, E.B. Schmit, S. Endes, Br. Hert J., 70, 212 (1993).

2) S.H. Goodnight, Arch. Pathol. Lab. Med., 117, 102 (1993).

3) W. Newman, J. Middaugh, M. Prost, D. Roger, Lancet, 341, 1056 (1993).

4) W.C. Harris, F.A. Rothrock, S.B. Inkeles, S.H. Goodnight, D.R. Illingworth, W.E. Corner, Am. J. Clin. Nutr. 51, 399 (1990).

5) K. Sakaguchi, I. Morita, S. Murota, Prostagland. Leuko. Essen. Fatty Acids, 50, 81 (1994).

6) N. Kromann, A. Green, Acta Med. Scand., 208, 401 (1980).

7) J.M. Kremer, D.A. Lawrence, W. Jubiz, R. Di Giacomo, K. Rynes, L.E. Bartholomew, M. Sherman, Arthritis. Rheum., 33, 810 (1990).

8) R.I. Sperling, R.A. Lewis, K.F. Austen, Arthritis. Rheum., 30, 987 (1987).

9) L.G. Cleland, J.K. French, W.H. Betts, G.A. Murphy, M.J. Elliott, J. Rheumatol., 15, 1471 (1988).

10) V.A. Ziboh, K.A. Cohen, C.N. Ellis, C. Miller, T.A. Hamilton, K. Kragballe, C.R. Hydric, J.J. Voorhees, Arch. Dermatol., 122, 1277 (1994).

11) U.N. Das, Prostagland. Leuko. Essen. Fatty Acids, 51, 207 (1994).

12) A.B. Hawthorne, T.K. Daneshmend, C.J. Belluzzi, S.J. Everitt, G.K.T. Holmes, C. Malkinson, M.Z. Shaheen, J.E. Willars, Gut, 33, 922 (1992).

13) A. Belluzzi, C. Brignole, M. Pera, M. Miglioloi, New Eng. J. Med., 334, 1557 (1996).

14) P.C. Calder, Biochem. Soc. Trans., 23, 302 (1995).

15) P.C. Calder, Biochem. Soc. Trans., 24, 211 (1996).

16) P.C. Calder, Proc.Nutr. Soc., 55, 127 (1996).

17) P.C. Calder, Nutr. Rev., 56, S70 (1998).

18) J.P. Arm, C.E Horton, J.M., Mencia-Huerta, F. House, M.N. Eiser, T.J.H. Clark, B.W. Spur, T.H. Lee, Thorax 43, 84 (1988).

19) A. Bjørneboe, E. Søyland, G-E.A. Brørneboe, G. Rajaka, C.A. Drevon, Br. J. Dermatol., 117, 463 (1987).
20) M.Uehara, S. Ofuji., Arch Dermatol., 81, 736 (1976).

21) A.D. Adinoff, P. Tellez, A.F. Clark, J. Allergy Clin. Immunol., 81, 736 (1988).

22) H.A. Sampson, J. Allergy Clin. Immunol., 81, 635 (1988).

23) M.Gerwe, K. Gyufko, E. Schopf, J. Krutmann, Lancet, 343, 25 (1994).

24) L.R. Braathen, O. Forre, J.B. Natvig, T. EegLarsen, Br. J. Dermatol. 100, 511 (1987).

25) G.B. Zachary, M.H. Allen, D.M. MacDonald, Br. J. Dermatol. 112, 149 (1987).

26) T.R. Mosman, R.L. Coffman, Ann. Rev. Immunol., 7, 145 (1989).

27) S. Yamazaki, H. Kumahara, H. Kakishima, J. Jpn. Oil Chem. Soc., (in Japanese) 117, 155 (1997).

28) J. Folch, M. Lees, G.A. Sloane-Stanley, J. Biol. Chem., 226, 497 (1957).

29) J.E. Kinsella, K.S. Broughton, J.W. Whelan, J. Nutr. Biochem., 1, 123 (1990).

30) J.D. Palombo, S.J. DeMichele, P.J. Boyce, E.E. Lydon, J.W. Liu, Y.S. Huang, R.A. Forse, J.P. Mizgerd, B.R. Bistrian, (in press) Crit. Care. Med.

31) H.E. Krokan K.S. Bjerve. E. Mork, Biochim. Biophys. Acta., 1168, 59 (1993).

32) E.J. Corey, C. Shin, J.R. Cashman, Proc. Natl. Acd. Sci. USA, 80, 3581 (1983).

33) M. Shikano, Y. Masuzawa, K. Yazawa, J. Immunol. 1503525 (1993).

34) K. Matsumoto, I. Morita, H. Hibino, S. Murota, Prostaglan. Leuko. Essen. Fatty Acids, 49, 861 (1993).

35) M. Bevilacqua, P.J. Mendrick, R. Cortran, M.J. Gimbrone, Proc. Natl. Acad. Sci. USA, 84, 9238 (1987).

36) T. Springer, Nature, 346, 425 (1990).

37) R. DeCaterin, M.I. Cybulsky, S.K. Clinton, M.A. Gimbrone Jr., P. Libby, Arterioscler Thromb., 14, 1892 (1994).

38) Y. Masuzawa, K. Abe, K. Matsuoka, K. Kishida, K. Watanabe, K. Yazawa, E. Tsuji, J. Lipid Nutr., (in Japanese) v 4, 124 (1995). 


\section{[報文］ｎ-3 系高度不飽和脂肪酸を含む食用油脂および}

\section{リン脂質は $2 ， 4-$ ジニトロ -1-フルオロベンゼンで マウスに誘導した接触皮膚炎を抑制する}

守 沢 和 也*1 ・ 友 部 (入鹿山) 容子*2 ・ 土田 衛*2

中野善郎苂 - 日比野 英彦*2 - 田中幸 久 ${ }^{* 2}$

*1 日本油脂株式会社 食品研究所（广 114-0003 東京都北区豊島 4-18-11）

*2 日本油脂株式会社 筑波研究所（テ 300-2635 茨城県つくば市東光台 5-10)

n-3 系多価不飽和脂肪酸を含有した食用油脂であるしそ油, tuna oil 及び鮭の魚卵リン脂質 (fish roe PL) は n-6 脂肪酸を含有するとうもろこし油に比べて 2,4-dinitro-1-fluorobenzene (DNFB) で誘引された耳介の接触皮膚炎 モデルの炎症反応を抑制する作用を持っている。Fish roe PL は耳介腫脹をもっとも強く抑制し, tuna oil 及び 漢方薬である柴朴湯がそれに続き， $\alpha$ リノレン酸を多量に含むしそ油はとうもろこし油に比べて抑制の傾向は見 られたが有意な差は見られなかった。炎症性の $\mathrm{CD} 4^{+} T$ 細胞の耳介への浸潤は fish roe PL 投与によって抑制され, 耳介において IFN- $\gamma$, IL-6, IL-1 $\beta$ の mRNA の発現抑制が観察された。本実験の結果で fish roe PL は遅延型の アレルギーを抑制する効果を持つことが示唆された。

（連絡者：田中幸久） Vol.49， No.1， 59 (2000)

\section{[ノート］C-24（28）位に二重結合を有する $\mathrm{C}_{28}$ ステロイドの合成}

高津戸 秀*1 . 後藤千 春*1 ${ }^{* 1}$ 鳴海 安 久 ${ }^{* 1}$

野口貴弘 ${ }^{* 2}$ - 藤岡 昭 三*3

*1 上越教育大学自然系化学教室 ( $\bar{\top} 943-8512$ 新潟県上越市山屋敷町 1)

*2 夕マ生化学 (广 163-0704 東京都新宿区西新宿 2-7-1)

*3 理化学研究所植物機能研究室 (T 351-0198 埼玉県和光市広沢 2-1)

シロイヌナズナの矮性変異体のシュートに含まれるステロイドを同定するための標品として, 24-methylcholesta-4,24 (28)-dien-3-one および 24-methyl-5 $\alpha$-cholest-24 (28) -en-3 $\beta$-ol を合成した。合成の 鍵反応として24-オキソステロイドの Tebbe 試薬によるオレフィン化を用いた。さらに，それらの関連化合物で ある 24-methylcholesta-4,24 (28) -dien-3 $\beta$-ol および 24-methyl-5 $\alpha$-cholest-24(28)-en-3-one の合成も行った。

（連絡者：高津戸 秀) Vol.49, No.1，67 (2000) 